\title{
Heifer Retention Program in the Pantanal: a study with data envelopment analysis (DEA) and Malmquist index
}

\section{Urbano Gomes Pinto de Abreu'1, Eliane Gonçalves Gomes², João Carlos Correia Baptista Soares de $\mathrm{Mello}^{3}$, Sandra Aparecida Santos ${ }^{1}$, Dalton Francisco Catto ${ }^{4}$}

\author{
${ }^{1}$ Embrapa Pantanal (CPAP), Corumbá, MS, Brazil. \\ ${ }^{2}$ Embrapa Sede, Brasília, DF, Brazil. \\ ${ }^{3}$ Universidade Federal Fluminense (UFF), Niterói, RJ, Brazil. \\ ${ }^{4}$ Banco do Brasil, Brasilia, DF, Brazil.
}

\begin{abstract}
The objective of this study was to propose Data Envelopment Analysis (DEA) models and non-parametric Malmquist indexes to evaluate the efficiency of 11 livestock farms in the Pantanal region. These farms took out a loan from 'Fundo Constitucional de Financiamento do Centro-Oeste' - FCO (Constitutional Financial Fund for the Midwest), a line of credit for financing heifer retention. The beneficiaries were the farmers whose properties met the following conditions: farms located in the plain of Pantanal, with at least $50 \%$ of native pasture; farms that were part of managerial capacity building projects intended to ensure better management and animal performance indexes; and farms with pasture areas where the activity could potentially evolve. The management of the loan on 11 farms were studied in relation to the technology introduced in the period from 2004 to 2008 . Five properties presented technical efficiency below 1, that is, the technical management efficiency with the objective to increase the cattle through heifer retention and the purchase of higher genetic quality heifers was not achieved. However, the index of technological progress was above 1 on all tested farms, which means that technology was in fact incorporated in all properties, which resulted in total factor productivity growth on all farms. The main objective was fully met, even on the technically inefficient farms.
\end{abstract}

Key Words: cattle business, efficiency, production system

\section{Introduction}

The decision-making process of rural producers is complex and almost always marked by multiple objectives. Among them there are economic and non-economic ones (Cezar et al., 2000). Regardless of the goals to be achieved, decisions of farmers will always be guided by dissatisfaction with the current situation. Achieving maximum efficiency and production does not mean to concentrate all efforts on a single component of the production system. Productive activities should be understood and managed within a systemic approach (Oiagen et al., 2009). In a production system, two types of efficiency are identified: the technical and the economic ones. A production system is considered technically efficient when there is no other system that provides the same level of production by using either the same or less quantity of inputs. Maximum economic efficiency occurs when there is no other alternative production system that produces the same amount, with lower cost or greater profit (Ferreira \& Gomes, 2009).

A performance indicator of a particular production system is its relative efficiency. Identifying the reasons for the efficiency or inefficiency of a production system contributes to the definition of appropriate strategies for the system development and also for problem solving. Correcting the causes of the inefficiency provides better use of the resources invested in the introduction and adaptation of technologies (Arzubi \& Berdel, 2002). The data envelopment analysis (DEA) was originally proposed by Charnes et al. (1978) as a methodology for assessing the relative efficiency of homogeneous units (called Decision-Making Units - DMU) with autonomy in the decision making process. It is a technique based on mathematical programming, developed to measure the relative performance of organizational units with the presence of multiple inputs and multiple outputs (Boussofiane et al., 1991). Currently, this methodology has been used in the most different research areas of production systems (Emrouznejad et al., 2008; Gomes, 2008).

The primary goal of DEA is to compare a certain number of firms (DMU) that perform similar tasks but differ in terms of the amount of inputs they consume and the amount of outputs produced. There are two equivalent formulations (duals) for DEA. The formulation called Envelopment Model defines a viable region of production and projects each DMU on the region frontier. The other 
formulation, the Multipliers model, calculates the ratio of the weighted sum of products and the weighted sum of resources, with the choice of "the most favorable weights" for every DMU according to certain conditions. The two classical DEA models are the CCR model (from Charnes, Cooper and Rhodes), which presupposes constant returns to scale, that is, increasing the amount of inputs leads to a proportional increase in the amount of outputs (Charnes et al., 1978), and the BCC model (from Banker, Charnes and Cooper), which considers production situations with variation of scale and does not assume proportionality between inputs and outputs (Banker et al., 1984).

In this case study, the changes in the productivity factors of each DMU in the 2004-2008 period were calculated by using geometric averages of two Malmquist indexes. The use of Malmquist indexes in measuring productivity changes was based on the existence of production technology that transforms an input vector into an output vector (Färe et al., 1994).

Aiming to encourage, facilitate and consolidate the development of beef cattle in the Pantanal plains, the deliberative Council (CONDEL) of Fundo Constitucional de Financiamento do Centro-Oeste (Constitutional Financial Fund for the Midwest) - FCO (2003), by means of resolution CONDEL/FCO n. 176, established a line of credit for heifer retention in the Pantanal plains. The term of financing was eight years, including the grace period of up to four years. The technologies adapted and developed by Embrapa Pantanal directed to livestock production in the Pantanal (Abreu, et al., 2006a) supported the specific financing program, aiming to increase both the number and the genetic quality of the cattle population in the Pantanal biome.

This study aimed to assess the efficiency and productivity of the production system applied by the producers who decided to use the FCO loan for heifer retention by means of Data Envelopment Analysis (DEA) and Malmquist indexes, and to assess its management practices in the introduction of technologies in the period from 2004 to 2008 .

\section{Material and Methods}

In the state of Mato Grosso do Sul, 92 projects were applied by means of the financing program, with the objective of retaining heifers in the Pantanal. The release of resources was conducted by Banco do Brasil (BB). In 2008, along with the rural credit team of the BB central agency in Mato Grosso do Sul, the authors of this experiment had access to 11 reports produced by private technical assistance that monitored the 2004 loans. All properties were located in the municipality of Corumbá, in Mato Grosso do Sul. In order to avoid their identification, the 11 farms analyzed were encoded with letters A-K.

One can observe that both big and small farms have taken out the loan (Table 1). The difference between the total areas of the largest and the smallest farms was over 24 thousand hectares. In all properties the native pasture was the main nutrition resource of the animals, as the average cultivated pasture area was 55.00 hectares. In other words, they were the typical properties of the region, where the presence of large areas with cultivated pasture is not common. The herds were all cow-calf with 48.65 and 50.58 of the total composed of heifers (female_3), in 2004 and 2008, respectively. On average, the stocking rate of the farms was 0.20 animal units (AU) per hectare in 2004, which favored the use of the loan to purchase females in order to increase the cow-calf herds in the properties. The models

Table 1 - Characteristics and structure of herds in 2004 and 2008, of the eleven farms that took out a loan in the Heifer Retention Program

\begin{tabular}{|c|c|c|c|c|c|}
\hline & & Average & Standard error & Minimum & Maximum \\
\hline \multirow{4}{*}{$\begin{array}{l}\text { Characteristics } \\
\text { of the farms }\end{array}$} & Total area (hectares) & $10,453.33$ & $2,252.47$ & 938.26 & $25,200.00$ \\
\hline & Stocking rate (heads/hectare) & 0.19 & 0.02 & 0.11 & 0.33 \\
\hline & Native pasture area (hectares) & $8,173.81$ & $1,797.72$ & 715.76 & $20,115.00$ \\
\hline & Cultivated pasture area (hectares) & 55.00 & 30.89 & 0 & 350.00 \\
\hline \multirow{5}{*}{$\begin{array}{l}\text { Structure of } \\
\text { the herd in } 2004\end{array}$} & Sire_2004 (heads) & 104.82 & 30.16 & 9.00 & 301.00 \\
\hline & Female 01_2004 (heads) & 381.36 & 120.28 & 28.00 & $1,254.00$ \\
\hline & Female 12_2004 (heads) & 490.09 & 133.46 & 48.00 & $1,555.00$ \\
\hline & Female 23_2004 (heads) & 334.27 & 84.63 & 47.00 & 932.00 \\
\hline & Female 3_2004 (heads) & $1,763.36$ & 444.34 & 51.00 & $4,527.00$ \\
\hline \multirow{6}{*}{$\begin{array}{l}\text { Structure of } \\
\text { the herd in } 2008\end{array}$} & Male 01_2008 (heads) & 625.36 & 222.11 & 24.00 & $2,498.00$ \\
\hline & Sire_2008 (heads) & 116.27 & 35.50 & 14.00 & 414.00 \\
\hline & Female 01_2008 (heads) & 671.91 & 205.75 & 83.00 & $2,385.00$ \\
\hline & Female 12_2008 (heads) & 444.45 & 130.31 & 46.00 & $1,547.00$ \\
\hline & Female 23_2008 (heads) & 294.82 & 59.69 & 47.00 & 578.00 \\
\hline & Female 3_2008 (heads) & $2,203.36$ & $6,55.93$ & 221.00 & $7,676.00$ \\
\hline
\end{tabular}

Male and female 01, 12, 23, 3 - male and female animals up to one year old, between one and two years old, between two and three years old, and over three years old, respectively, in 2004 and 2008 . 
used were DEA CCR multipliers and Envelopment, as the DMU were considered similar both in the technological level and in the adoption of technologies after taking out the FCO loan. In addition, the CCR model was more adequate to the analysis, due to the proportionality of the inputs and outputs of the DMU analyzed. Each DMUk, $k=1 \ldots n$ was considered as a production unit that uses $m$ inputs $x_{i k}, i=1 \ldots$ $m$ to produce $s$ outputs $y_{j k}, j=1 \ldots s$. In formulations (1) and (2), ho is the efficiency of the DMUo under analysis; $x_{i o}$ and $y_{\text {jo }}$ are the inputs and outputs of the DMUo. In (1), $v_{i}$ and $u_{j}$ are the weights that are calculated by the model for inputs and outputs, respectively. In (2) $\lambda_{k}$ represented the contribution from DMUk in the formation of the target of DMUo. If $\lambda_{k} \neq 0$, DMUk is a benchmark for DMUo. The formulations and details of other classical and advanced DEA models are presented in Cooper et al. (2004).

Min $h_{o}=\sum_{i=1}^{m} v_{i} x_{i o}$

subject to

$\sum_{j=1}^{s} u_{j} y_{j o}=1$

$\sum_{j=1}^{s} u_{j} y_{j k}-\sum_{i=1}^{m} v_{i} x_{i k} \leq 0, \forall k$

$u_{j}$ e $v_{i} \geq 0, \forall j, i$

The preliminary selection of variables was based on data availability and the opinion of specialists. Overall, the variables selected were those that best described the performance of the units under assessment.

The choice of the variables used in the analysis was according to the methodology developed by Senra et al. (2007), who proposed the combinatorial multicriteria method by scenarios (MMCC). This method maintains the stopping rule from the multicriteria method developed by Soares de Mello et al. (2004) and has two stages. In the first stage the scenarios are tested until all variables have been considered. In the second phase, the indexes are recalculated, in order to better adjust to the frontier (measured by average efficiency, index SEF) and better discriminate the units (assessed by the amount of efficient DMU, index SDIS). The selected variable was the one that produced the highest value according to the criterion of synthesis (aggregated S index). The use of MMCC in systemic analysis of beef cattle production was described by Abreu et al. (2008a) in detail.

The analysis of the reports led to the identification of the variables that would constitute the DEA model, namely, the total area of the farm, stocking rate (animals/area), native pasture area, legal reserve area (an area which, by law, cannot be anthropized), area with planted pasture, permanent preservation area, improvements (value of existing improvements in the property, estimated by the technical assistance agents), number of males and females $01,23,12,3$ (amount of male and female animals up to one year old, between one and two years old, between two and three years old, and over three years old, respectively), total livestock units, total workforce, financing (in Brazilian Reais, without correction; total resource borrowed from FCO to prevent the producer from selling the females), number females financed (amount of females corresponding to financing).

An expert in the livestock of the region was consulted and identified, among the variables mentioned, the best ones for the modeling. The variables selected for 2004 were: total area, native pasture area, financing, total animal units, as inputs; financed females, females 01 , females 12 , females 23 and females 3 , total females (sum of all females in the property) as outputs. The variables for 2008 were: total area, natural pasture area, financing, total animal units, as inputs; females 01 , females 12 , females 23 , females 3 , total females, male 01 , male 12 , male 23 , male 3 , females + males, sires, as outputs. The input variables were not submitted to the MMCC method. In fact, according to the opinion of the expert, as the loan aimed to retain heifers, two inputs were mandatory in the model: the value of the loan, and the number of native pasture hectares informed in the rural land tax of farms in 2004. In order to avoid a large number of variables, with consequent reduction of the analytic power of the model, the other possible input variables were not used. The output selection was made with the use of the multicriteria method of single standardization, as described by Angulo Meza et al. (2007). Thus, in order to select which of the variables should compose the model, various DEA models were run with the two inputs already chosen and with each one of the possible outputs.

The Malmquist productivity index (product oriented) is defined as the ratio of two distance functions. The index enables the measurement of the productivity development between periods, based on calculation of the distance that separates each note of the reference technology in each period, by using distance functions. For a given production technology $S^{t}=\left\{\left(x^{t}, y^{t}\right): x^{t}\right.$ produce $\left.y^{t}\right\}$, a distanceproduct function may be defined for period $t$, as shown below:

$D_{0}^{t}\left(x^{t}, y^{t}\right)=\inf \left[\theta:\left(x^{t}, y^{t} / \theta\right) \in S^{t}\right]=\left\{\sup \left[\theta:\left(x^{t}, \theta y^{t}\right) \in S^{t}\right]\right\}^{-1}$

Therefore, the distance function is defined as the inverse of the maximum proportional increment of the production vector $y^{t}$, given the $x^{t}$ input vector. In the special case of a single product, the distance-product function may be represented by $D_{0}^{t}\left(x^{t}, y^{t}\right)=y^{t} / F\left(x^{t}\right)$, in which $F\left(x^{t}\right)$ is a production

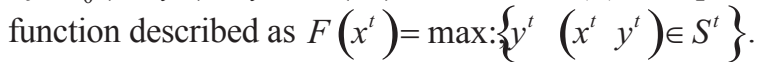

R. Bras. Zootec., v.41, n.8, p.1937-1943, 2012 
If the DMU is technically efficient, i.e., if $\left(\mathrm{x}^{\mathrm{t}}, \mathrm{y}^{\mathrm{t}}\right)$ are on the technological border, then $D_{0}^{t}\left(x^{t}, y^{t}\right)=1$. If $D_{0}^{t}\left(x^{t}, y^{t}\right)<1$, the DMU at instant $t$ is within the technological frontier and $\left(x^{t}, y^{t}\right)$ is not technologically efficient. The distance-product function for the period $t+1$ may be obtained from (3), by replacing $t$ by $t+1$.

The Malmquist productivity index may be represented by the geometric mean of two quotients of distance-product functions, as shown in (4).

$M_{o}\left(x^{t+1}, y^{t+1}, x^{t}, y^{t}\right)=\sqrt{\frac{D_{o}^{t}\left(x^{t+1}, y^{t+1}\right)}{D_{o}^{t}\left(x^{t}, y^{t}\right)} \frac{D_{o}^{t+1}\left(x^{t+1}, y^{t+1}\right)}{D_{o}^{t+1}\left(x^{t}, y^{t}\right)}}(4)$

The index therefore uses distance functions from two different periods or technologies, $D_{0}^{t}(.,$.$) and D_{0}^{t+1}(.,$.$) two$ pairs of input-output vectors, $\left(x^{t}, y^{t}\right)$ and $\left(x^{t+1}, y^{t+1}\right)$ and may be decomposed into two components, according to (5).

$M_{o}\left(x^{t+1}, y^{t+1}, x^{t}, y^{t}\right)=\frac{D_{o}^{t+1}\left(x^{t+1}, y^{t+1}\right)}{D_{o}^{t}\left(x^{t}, y^{t}\right)} \sqrt{\frac{D_{o}^{t}\left(x^{t+1}, y^{t+1}\right)}{D_{o}^{t+1}\left(x^{t+1}, y^{t+1}\right)} \frac{D_{o}^{t}\left(x^{t}, y^{t}\right)}{D_{o}^{t+1}\left(x^{t}, y^{t}\right)}}$

The quotient out of the root (3) $\left[E\left(x^{t+1}, y^{t+1}, x^{t}, y^{t}\right)\right]$ is an index of change in the relative efficiency (technical efficiency) under constant returns to scale between periods $t$ and $t+1$. The geometric mean in (5) $\left[T\left(x^{t}+1, y^{t}+1, x^{t}, y^{t}\right)\right]$ is an index of technical change (technological progress), which represents the displacement of the technological frontier between the two periods of time assessed under the input vectors $x^{t}$ and $x^{t+1}$. The decomposition of the Malmquist index enables the identification of the contributions of efficiency changes and technological innovations to the DMU. Malmquist indexes higher than 1 indicate productivity growth, whereas values smaller than 1 point to a decline in productivity, and an index equal to 1 indicates stagnation.

Table 2 - Choice of output for 2004 and $2008^{1}$

\begin{tabular}{lccccc}
\hline & \multicolumn{2}{c}{ Efficiency_2004 } & \multicolumn{3}{c}{ Efficiency_2008 } \\
\cline { 2 - 6 } DMU & $\begin{array}{c}\text { Females } \\
\text { 01 }\end{array}$ & $\begin{array}{c}\text { Total } \\
\text { females }\end{array}$ & $\begin{array}{c}\text { Females } \\
01\end{array}$ & $\begin{array}{c}\text { Total } \\
\text { females }\end{array}$ & $\begin{array}{c}\text { Females }+ \\
\text { males }\end{array}$ \\
\hline A & 0.7463 & 0.8334 & 0.4303 & 0.5219 & 0.5468 \\
B & 0.9850 & 0.7969 & 0.6354 & 0.6229 & 0.6660 \\
C & 0.3899 & 0.5550 & 0.4434 & 0.4239 & 0.4696 \\
D & 0.3728 & 0.4894 & 0.4127 & 0.3813 & 0.4064 \\
E & 0.2446 & 0.5104 & 0.3229 & 0.3361 & 0.3570 \\
F & 0.3404 & 0.4185 & 0.6471 & 0.6027 & 0.7559 \\
G & 0.9859 & 0.6179 & 0.4063 & 0.4025 & 0.4414 \\
H & 0.8864 & 0.5991 & 0.3795 & 0.3968 & 0.4183 \\
I & 1.0000 & 0.8177 & 0.5506 & 0.5217 & 0.5425 \\
J & 0.9687 & 1.0000 & 1.0000 & 1.0000 & 1.0000 \\
K & 0.6425 & 0.5910 & 0.3482 & 0.4181 & 0.4514 \\
SEF & 0.6875 & 0.6572 & 0.5069 & 0.5116 & 0.5505 \\
SDIS & 1.0000 & 1.0000 & 1.0000 & 1.0000 & 1.0000 \\
S & 0.8438 & 0.8286 & 0.7535 & 0.7558 & 0.7752 \\
\hline
\end{tabular}

${ }^{1}$ Inputs: native pasture and financing for the 11 decision-making units (DMU) evaluated. A-K - 11 farms assessed; SEF - higher average efficiency; SDIS - lowest number of efficient DMU; S - criterion of synthesis.

\section{Results and Discussion}

In the MMCC, the higher the average efficiency and the lower the amount of efficient DMU, the better the model discriminates and indicates the best performance. In 2004, the output that generated the best result was females 01 (Table 2). As proposed by Soares de Mello et al. (2004), SEF refers to the criterion of best adjustment to the frontier (the highest average efficiency), SDIS is the criterion of best discrimination (lowest number of efficient decisionmaking units), and $\mathrm{S}$ is the criterion of synthesis, which aggregates $\mathrm{S}_{E F}$ and $\mathrm{S}_{D I S}$. The variable selected is the one that produces the highest value of the aggregate index $\mathrm{S}$. In 2008 , the best model was the one that had females+males as output, due to the highest value of the aggregate index observed (0.7752). The result possibly reflects a better performance of the producers, who retained a greater number of females and also produced a greater number of males_01 in 2008.

According to Senra et al. (2007), the results of these models should not be mandatory, but should guide the decision-maker and the analyst in the construction of the model. It would be desirable to have the same model for both years. As there is no information about the total males in 2004 or the $\mathrm{S}$ index for the models with males+females, females 01 and total females were very similar, the variable males was not taken into account. Thus, two models were used, with female 01 and total females as outputs (one in each model) and pasture area and financing as inputs. The efficient farms are the ones that better used the inputs in order to meet the objective of retaining heifers to increase the herd.

Considering the models of the two years separately, in 2008 the average efficiency was lower. This result does not mean that there was poorer efficiency, since the DMU are compared with one another in the same year. It just means that in 2008 there was a greater dispersion of the DMU. The efficient farms became more efficient, perhaps by using the loan in a better way, and/or the inefficient ones got worse.

When an analysis of the type "time window" is carried out, in which a property in one year is a different DMU from the same property in another year, the evolution of the properties may be better assessed (Table 3 ). In this case there was indication of significant improvement of the efficiency of the properties from 2004 to 2008 . This was probably due to management after the financing and the incorporation of technology into the extensive production system; the contract stated that the producer would incorporate the technologies developed by Embrapa Pantanal and described by Abreu et al. (2006a). The result is consistent with what 
was observed by Abreu et al. (2006b), who conducted a case study at a property in the Pantanal. The study revealed increased efficiency in managing the cash flow of the farm on which technologies were introduced.

The DMU with the highest percentage growth of heifers in the period were those which presented the highest technical efficiency. All farms that incorporated the management practices agreed when the loan was taken, which probably contributed to the retention of heifers and enabled the increase of technological progress on all farms, thus reaching the goal of heifer retention. The decisionmaking units $\mathrm{G}, \mathrm{H}$ and I were the ones with the worst productive performance in relation to the growth of heifers, which reflected on low efficiency estimate.

The data available in the 11 reports showed that these were properties with predominant native pasture areas, considered to be of medium size in the Pantanal, according to the productive profile found by means of the 'panel' type analysis of the modal property in the Pantanal in Corumbá - Mato Grosso do Sul, as described by Carvalho et al. (2009). Another important aspect was the number of heifers in the category of up to one year of age, which increased $76.19 \%$ on average in the period assessed (2004 to 2008). The Pantanal is an area with predominance of cow-calf herds, where heifer retention and management are considered aspects of importance to the economic sustainability of the producer, since the replacement by better genetic heifers is important for the stability and genetic improvement of the cattle population (Maquivar \& Galina, 2010). On the other hand, according to Abreu et al. (2003), the sale of the surplus represents an important source of income for beef cattle farmers.

The same inputs of the DEA model were considered, namely, financing and pasture area (Table 4). The output variable was the number of heifers up to 12 months of age (females_01) that the farmer had in 2004 and the amount

Table 3 - Model of time windows ${ }^{1}$

\begin{tabular}{lccccc}
\hline \multicolumn{5}{c}{ Efficiencies - 2004 and 2008 } \\
\hline DMU & $\begin{array}{c}\text { Females } \\
\text { 01 }\end{array}$ & $\begin{array}{c}\text { Females } \\
\text { total }\end{array}$ & $\begin{array}{c}\text { DMU } \\
\text { 2008 }\end{array}$ & $\begin{array}{c}\text { Females } \\
01\end{array}$ & $\begin{array}{c}\text { Females } \\
\text { total }\end{array}$ \\
\hline A-2004 & 0.2729 & 0.5642 & A-2008 & 0.4303 & 0.5219 \\
B-2004 & 0.4900 & 0.5395 & B-2008 & 0.6354 & 0.6229 \\
C-2004 & 0.1426 & 0.3757 & C-2008 & 0.4434 & 0.4239 \\
D-2004 & 0.1363 & 0.3314 & D-2008 & 0.4127 & 0.3813 \\
E-2004 & 0.0894 & 0.3455 & E-2008 & 0.3229 & 0.3361 \\
F-2004 & 0.1693 & 0.2833 & F-2008 & 0.6471 & 0.6027 \\
G-2004 & 0.3606 & 0.4183 & G-2008 & 0.4063 & 0.4025 \\
H-2004 & 0.3700 & 0.4056 & H-2008 & 0.3795 & 0.3968 \\
I-2004 & 0.4974 & 0.5536 & I-2008 & 0.5506 & 0.5217 \\
J-2004 & 0.3543 & 0.6770 & J-2008 & 1.0000 & 1.0000 \\
K-2004 & 0.2516 & 0.4001 & K-2008 & 0.3482 & 0.4181 \\
\hline
\end{tabular}

${ }^{1}$ Inputs: pasture area and financing; Outputs: females 01 and females total.

A-K - 11 farms assessed according to the year of assessment (2004 and 2008); DMU - decision-making unit. after four years of project development (2008). All DMU exhibited productivity growth. However, there was a decrease of technical efficiency on most farms during the period, as the values were smaller than one, i.e., there was a decrease of the relative efficiency in the management of the variables in the production system, when the 2004 efficiency was compared with 2008. This shows that the management (technical efficiency) of the input variables, in the 2004-2008 period, may be improved in the DMU with values below one. On the other hand, there was a significant technological improvement measured by technological progress, with values above one in all properties assessed, which enabled the identification of innovation in the production system (Grosskopf, 2003). This was probably due to the incorporation of technologies developed by Embrapa Pantanal (Abreu, et al., 2006a), whose application was one of the requirements for the loan. The weight of the innovation component (technological progress) led the DMU estimates of the Malmquist Index (tfpch) to remain above one, which indicates the growth of the total productivity of the factors, as described by Färe et al. (1994).

The DMU F was the one with the highest productivity index (3.82) among the farms assessed. It is also the one with the smallest area (906 hectares of natural pasture) and the lowest amount of financed heifers. Such result is consistent with the result obtained with the use of the DEA methodology "time windows". The DMU with the highest percentage growth of heifers in the period presented the best technical efficiency.

All properties incorporated management practices, with a consequent increase of technological progress, even considering the fact that in the Pantanal, according to Abreu et al. (2008b), the extensive beef cattle producers faced the problem of low prices of weaning calves, which is the main category commercialized in the region.

Table 4 - Non-parametric index of Malmquist (tfpch), technical efficiency (effch) and technological progress (techch) of the DMU, in the period from 2004 to 2008

\begin{tabular}{lccc}
\hline DMU & tfpch & effch & techch \\
\hline A & 1.57 & 0.57 & 2.73 \\
B & 1.29 & 0.64 & 2.01 \\
C & 3.10 & 1.13 & 2.73 \\
D & 3.02 & 1.10 & 2.73 \\
E & 3.61 & 1.32 & 2.73 \\
F & 3.82 & 1.90 & 2.01 \\
G & 1.12 & 0.41 & 2.73 \\
H & 1.02 & 0.42 & 2.39 \\
I & 1.10 & 0.55 & 2.01 \\
J & 2.82 & 1.03 & 2.73 \\
K & 1.38 & 0.54 & 2.55 \\
Mean & 1.92 & 0.77 & 2.46 \\
\hline
\end{tabular}

A-K - 11 farms assessed; DMU - decision-making unit. 


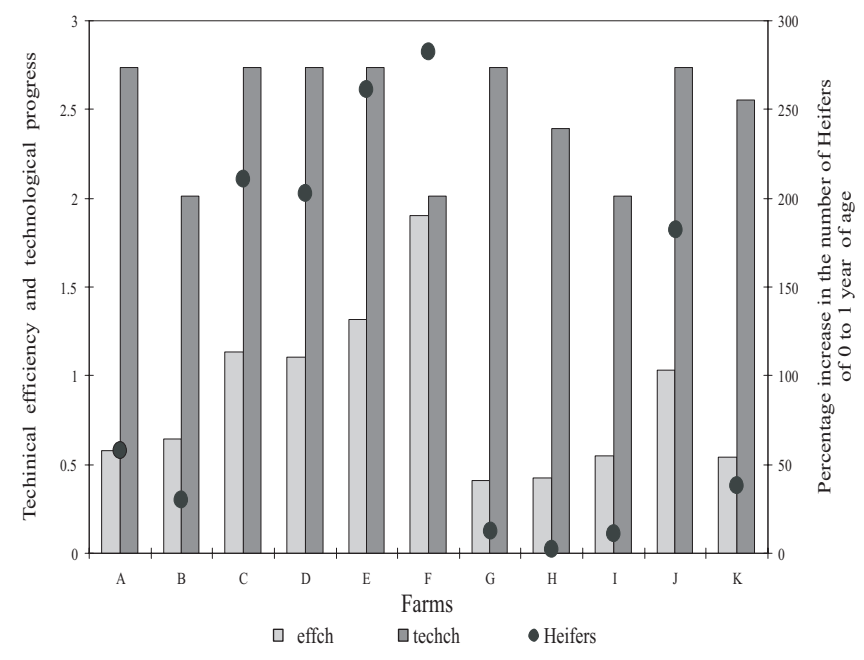

Figure 1 - Technical efficiency (effch) and technological progress (techch) indexes in relation to the percentage growth of 0 to 1 -year-old heifers, in the period from 2004 to 2008 .

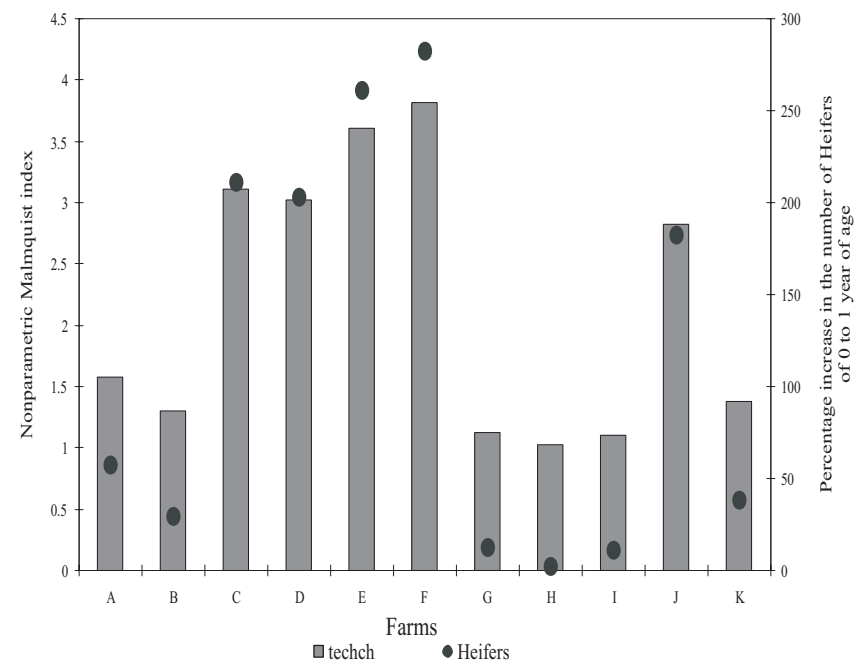

Figure 2 - Non-parametric Malmquist index in relation to the percentage growth of $0-1$ year-old heifers in the period from 2004 to 2008 .

The decision-making units $\mathrm{B}, \mathrm{G}, \mathrm{H}, \mathrm{I}$ and $\mathrm{K}$ presented the worst productive performance in relation to the growth of the number of heifers, which reflected in low estimate of relative efficiency; consequently, the Malmquist indexes of these DMU were the closest to one, which means stagnation (Figure 2).

The financing program for heifer retention and herd growth was probably not successful due to managerial problems, which reflected in the stagnation of the number of heifers in the period. On the other hand, there was growth in the number of heifers 01 in the other decision-making units.
The Pantanal is an environmentally fragile region, still not very much changed, and its conservation is very important. The livestock production developed in the region is considered the main activity responsible for the current state of conservation of the region (Abreu et al., 2010). Thus, modern management techniques should be incorporated so as to increase the income of the producer and the sustainability of the activity.

\section{Conclusions}

The credit line for heifer retention met the objective to introduce technologies in the extensive production system in the Pantanal, and, in parallel, retain heifers in order to recompose the cow-calf herd in the region. In spite of the fact that the activity management was not optimized in some properties, the incorporation of new management techniques provided technological progress to the activity.

\section{References}

ABREU, U.G.P.; McMANUS, C.; SANTOS, S.A. Cattle ranching, conservation and transhumance in Brazilian Pantanal. Pastoralism - Research, Policy and Practice, v.1, p.99-114, 2010.

ABREU, U.G.P.; GOMES, E.G.; LOPES, P.S. et al. Avaliação sistêmica da introdução de tecnologias na pecuária de gado de corte do Pantanal com modelos de análise envoltória de dados (DEA). Revista Brasileira de Zootecnia, v.37, p.2069-2076, 2008 a.

ABREU, U.G.P.; CARVALHO, T.B.; MORAES, A.S. Análise do preço do bezerro pago no Pantanal da Nhecolândia, no período de 2001 a 2008. Corumbá: Embrapa Pantanal, 2008b. 7p. (Comunicado Técnico, 70).

ABREU, U.G.P.; LOPES, P.S.; TORRES, R.A. et al. Avaliação da introdução de tecnologias no sistema de produção de gado de corte no Pantanal. Desempenho e descarte de matrizes. Revista Brasileira de Zootecnia, v.35, p.2496-2503, 2006a.

ABREU, U.G.P.; LOPES, P.S.; BAPTISTA, A.J.M. et al. Avaliação da introdução de tecnologias no sistema de produção de gado de corte no Pantanal. Análise de eficiência. Revista Brasileira de Zootecnia, v.35, p.1242-1250, 2006b.

ABREU, U.G.P.; CEZAR, I.M.; TORRES, R.A. Análise bioeconômica da introdução de período de monta em sistemas de produção de rebanhos de cria na região do Brasil Central. Revista Brasileira de Zootecnia, v.32, p.1198-1206, 2003.

ANGULO MEZA, L.; SOARES DE MELLO, J.C.C.B.; GOMES, E.G. et al. Seleção de variáveis em DEA aplicada a uma análise do mercado de energia elétrica. Investigação Operacional, v.27, p.21-36, 2007.

ARZUBI, A.; BERBEL, J. Determinación de índices de eficiência mediante DEA em explotaciones lecheras de Buenos Aires. Investigaciones Agrárias: Producción y Sanidad Animales, v.17, p.103-123, 2002.

BANKER, R.; CHARNES, A.; COOPER, W.W. Some models for estimating technical and scale inefficiencies in Data Envelopment Analysis. Management Science, v.30, p. 1078-1092, 1984.

BOUSSOFIANE, A.; DYSON, R.G.; THANASSOULIS, E. Applied data envelopment analysis. European Journal of Operational Research, v.52, p.1-15, 1991.

CARVAlHO, T.B.; ABREU, U.G.P.; ALMEIDA, B.S. Custo de Produção em Pecuária de Corte em 2009, no Pantanal de Corumbá (MS). Corumbá: Embrapa Pantanal, 2009. 6p. (Comunicado Técnico, 76). 
CEZAR, I.M.; SKERRATT, S.; DENT; J.B. Sistema participativo de geração e transferência de tecnologia para pecuaristas: o caso aplicado à Embrapa Gado de Corte. Caderno de Ciência \& Tecnologia, v.17, n.2, p.135-170, 2000.

CHARNES, A; COOPER, W.W.; RHODES, E. Measuring the efficiency of decision-making units. European Journal Operational Research, v.2, p.429-444, 1978.

COOPER, W.W.; SEIFORD, L.M.; ZHU, J. Handbook on data envelopment analysis. Boston: Kluwer Academic Publishers, 2004. 608p.

EMROUZNEJAD, A.; PARKER, B.R.; TAVARES, G. Evaluation of research in efficiency and productivity: A survey and analysis of the first 30 years of scholarly literature in DEA. Socio-Economic Planning Sciences, v.42, p.151-157, 2008.

FÄRE, R.; GROSSKOPF, S.; NORRIS, M. et al. Productivity growth, technical progress and efficiency change in industrialized countries. American Economic Review, v.84, p.66-83, 1994.

FUNDO CONSTITUCIONAL DE FINANCIAMENTO DE CENTRO-OESTE - FCO. 2.ed. Fev., 2009. Report. Available at: $<$ http://www.integracao.gov.br/fundos/fundos_constitucionais/ index.asp?area=FCO\%20-\%20Programação\%202009>. Accessed on: May 19, 2009.
FERREIRA, C.M.C.; GOMES, A.P. Introdução à análise envoltória de dados - Teoria, modelos e aplicações. 1.ed. Viçosa, MG: Editora UFV, 2009. 389p.

GOMES, E.G. Uso de modelos DEA em agricultura: revisão da literatura. Engevista, v.10, p.27-51, 2008.

GROSSKOPF, S. Some remarks on productivity and its decompositions. Journal of Productivity Analysis, v.20, p.459-474, 2003.

MAQUIVAR, M.; GALINA, C.S. Factors affecting the readiness and preparation of replacement heifers in tropical breeding environments. Reproduction in Domestic Animals, v.45, p.937-942, 2010.

OIAGEN, R.P.; BARCELLOS, J.O.J.; CHRISTOFARI, L.F. et al. Análise da sensibilidade da metodologia dos centros de custos mediante a introdução de tecnologias em um sistema de produção de cria. Revista Brasileira de Zootecnia, v.38, p.1155-1162, 2009.

SENRA, L.F.A.C.; NANCI, L.C.; SOARES DE MELLO, J.C.C.B. et al. Estudo sobre métodos de seleção de variáveis em DEA. Pesquisa Operacional, v.27, p.191-207, 2007.

SOARES DE MELLO, J.C.C.B.; GOMES, E.G.; ANGULO MEZA, L. et al. Selección de variables para el incremento del poder de discriminación de los modelos DEA. Revista Investigación de la Escuela de Perfeccionamiento en Investigación Operativa, n. 24, p.40-52, 2004. 